\title{
The Effect of Economic Growth and Urbanization on Poverty Reduction in Vietnam
}

\author{
Huyen Thi Thanh NGUYEN ${ }^{1}$, Chau Van NGUYEN ${ }^{2}$, Cong Van NGUYEN ${ }^{3}$
}

Received: May 02, 2020 Revised: May 10, 2020 Accepted: June 07, 2020

\begin{abstract}
This article aims to measure the impact of economic growth and urbanization on poverty reduction in Vietnam, and verify whether economic growth and urbanization will help reduce poverty rates. Data for this study are tabular data related to growth, urbanization and poverty at the provincial level for the period of nine years, from 2006 to 2014 provided by the Vietnam General Statistics Office and the Vietnam General Department of Customs. The level of economic growth and urbanization mentioned in the study is reflected in such indicators as GDP value, exports value, imports value, urbanization rate and employment rate. The authors used logistic regression models with fixedeffects and logistic regression models with random effects. With 5\% confidence level tested by the Chi-Square test of Hausman trial with the fixed-effect model, research results show that: (1) factors with significant negative impact on the poverty rate include imports value, urbanization rate and, employment rate; (2) factors that do not affect the poverty rate include exports value and GDP value. Based on the research results, this study proposes a number of policy recommendations to help promote economic growth, to sustain the urbanization process, and to contribute directly and positively to poverty reduction in Vietnam.
\end{abstract}

Keywords : Economic Growth, Poverty Reduction, Urbanization, Vietnam.

JEL Classification Code: I30, I32, O15, O18.

\section{Introduction}

Poverty reduction is determined as the key socioeconomic development of the countries and it is recognized as a social phenomenon. According to Shah (2011), poverty does not only happen in low or middle-income countries, but also in developed countries. In this context, the governments in any country must pay attention to actions that help to ensure gradual poverty reduction. It is also true in the case

${ }^{1}$ First Author. Faculty of Environmental, Climate Change and Urban Studies, The National Economics University (NEU), Vietnam. Email: huyennt@neu.edu.vn

${ }^{2}$ UHY Auditing and Consulting Company Limited, Vietnam. Email: chaunv@uhyvietnam.com.vn

${ }^{3}$ Corresponding Author. Professor, The National Economics University (NEU), Vietnam [Postal Address: 207 Giai Phong, Dong Tam, Hai Ba Trung, Hanoi, 113068, Vietnam] Email: anhcongtuan@gmail.com

(c) Copyright: The Author(s)

This is an Open Access article distributed under the terms of the Creative Commons Attribution Non-Commercial License (http://Creativecommons.org/licenses/by-nc/4.0/) which permits unrestricted noncommercial use, distribution, and reproduction in any medium, provided the original work is properly cited. study of Vietnam since the government has been taking many actions to sustain poverty reduction. The importance of sustainable poverty reduction is relevant to the situation of Vietnam in changing its economic development from heavily state-managed to market-oriented since 1986. Up to now, Vietnam has achieved many outstanding results in terms of economic development, high urbanization rate, and better living standards for people. The effect of economic renovation impacts positively on the poverty situation of the country and it contributes directly to higher socio-economic development.

Vietnam is rated as one of the fastest economic development in the world. The report from The World Bank (2019) shows that Vietnam is a successful story of economic renovation and poverty reduction. From 2002 to 2018, more than 45 million people were taken out of poverty. The poverty rate dropped sharply from over $70 \%$ to less than 6\% (US\$3.2/day PPP) and GDP per capita increased 2.5 times, standing above US\$2,500 in 2018. Although poverty is declining at a high rate, Vietnam is still in the group of low-middle income countries. The average income per capita of Vietnamese people is only USD2,539/person/ 
year, ranked $128 / 180$ economies in the world. GDP in the industrial sector accounts for a very high proportion (13\%) and the number of people working in agriculture is still nearly $70 \%$. The urbanization rate is also less than $40 \%(\mathrm{Le}$, 2020). Although poverty in Vietnam has greatly decreased, there is still a strong requirement from the government to commit to further poverty reduction and to boost economic growth.

The importance and the result of poverty reduction in Vietnam are highlighted by different researchers, showing that it is playing a prominent role in the country. The study of factors affecting poverty and the implications of poverty reduction policies for ethnic Khmer in Tra Vinh province, by Nguyen and Nguyen (2019) shows the causes of poverty are: lack of capital for production, lack of production facilities, poor health and labor, large families, lack of job opportunities or unemployment, and a lack of willingness to escape poverty and education. The study by Giang, Nguyen, and Nguyen (2020) on the impact of economic growth and governance on migration finds that people tend to move from low-income provinces to highincome provinces and that migration is also associated with quality of governance and public administration. The study by Nguyen, Nguyen, Nguyen, and Nguyen (2020) about the impact of international integration on Vietnam's rural and urban income inequality indicates that, in the process of economic integration, the relevant exports and GDP factors are negatively related to income inequality; the remaining factors (GDP per capita, FDI/ GDP, educational level of households, Internet user ratio, aggregation of foreign cash inflow, and GDP of the province) are all positively related to income inequality. A study of economic growth, inequality and poverty in Vietnam by Nguyen and Pham (2018) finds that, although the rate of poverty reduction in the 2000s was lower than in the 1990s, the growth of the economy is still slow in the later period. In the period 1993-98, expenditure inequality increased and poverty reduction during this period was mainly due to economic growth. However, in the period 2004-08, expenditure inequality was reduced, thus contributing to poverty reduction. The poverty rate decreased by about five percentage points, of which expenditure growth and redistribution contributed 2.8 and 2.2 percentage points, respectively. Although empirical evidences support that economic growth processes also have a positive impact on poverty reduction, the nature of urban-rural urbanization and the transformation can affect the speed of poverty reduction: how the world urbanizes may well be as important as urbanization itself. However, these studies do not convey the findings of the relationship between poverty reduction and other socioeconomic factors such as urbanization and economic development.

\section{Literature Review}

In recent years, there have been many empirical studies on the relationship between economic growth, urbanization, and poverty reduction. Jack (2009) examined the current situation and the linkages between urbanization, sustainable growth, and poverty reduction in Asia. It identified that some of the challenges of urbanization related to land use, projected growth of slums, shelter provision, and infrastructure provision, social services and low income. Poor living conditions undermine efforts to overcome poverty and achieve millennium development goals. The importance of working partnerships between the urban poor, local authorities, and other stakeholders is well recognized.

Ravallion, Chen, and Sangraula (2007) conducted a study of urbanization and global poverty. The key finding shows that the urbanization process helps to reduce absolute poverty. However, there is a negative effect from urbanization on whether this process fuels the higher poverty in urban areas due to higher inequality among people from different social classes. This study also examines this linkage in different parts of the globe. They identify that Latin American people in the urban area are heavily impacted by the urbanization process, while it impacts less on people in Asia. These researchers also identify that urbanization process in Africa is not associated with higher poverty rate in urban area.

Sinding, (2009) carried out a study about the interrelationship between population, economic growth, and poverty reduction. This researcher shows that poverty reduction can be enhanced through the reduction of fertility and less reliance on working age in population structure. To guarantee that the number of people living under poverty line is lowered, the governments must incorporate some socioeconomic policies such as effective population management policies and higher investment into public services such as healthcare system and education system. In addition, the government must provide long-term plan for human development through clear national programs. According to Sinding (2009), poverty reduction is a key objective of any nation and he concluded that poverty reduction and economic growth are intertwined with one another. Moreover, the population is different in each country and therefore each government must conduct different plans to cope with poverty.

Omolo (2012) conducted a study about the impact of trade liberalization on poverty in Kenya. This researcher examines the relationship between trade liberalization and poverty in two scenarios: one refers to tariff reduction and the other refers to tariff totally removed. In both scenarios, the main conclusion is that full liberalization has greater impact on welfare than partial liberalization. Moreover, Omolo (2012) identifies that the urban poorest is more vulnerable than others when the countries open their economy to 
international trade, and therefore it is recommended that the governments should develop policies to reduce negative effects. Mitra (2016) examined the pros and the cons of trade liberalization on poverty reduction. He identifies that trade promotes incomes and economic growth and therefore lead to poverty reduction. This conclusion is confirmed by previous studies with large datasets and cross-country analysis. However, there are some cons related to the impact of trade liberalization on poverty reduction. At first, Mitra (2016) cannot find the causal relationship between trade liberalization and poverty reduction looking at India and China. Moreover, the result from cross-country regression between trade liberalization and poverty reduction is not statistically significant.

Turok and McGranahan (2020) published research about the relationship between urbanization and the economic growth rate in Africa and Asia. The key finding shows that there is no visible linkage between urbanization and economic growth in the data examined. Moreover, these researchers cannot find an association between productivity and city size. They point out the importance of realistic population projections as the basis for public infrastructure establishment and institutional settings. From this basis, they recommend the governments in Africa and Asia can find the solutions to remove the imbalance in policies treatment between urban and rural areas, enable forms of urbanization that contribute to growth, poverty reduction and environmental sustainability, rather than encouraging (or discouraging) urbanization per se.

Understanding the impact of urbanization on rural poverty in Indian districts, Calì and Menon(2013) found that urbanization has a significant and systematic impact on poverty reduction in the surrounding rural areas. The main reason lies in the positive spread of urbanization into the rural economy rather than the movement of the rural poor into urban areas. The rural poverty reduction impact of urbanization is explained mainly by the increased demand for local agricultural products and to a lesser extent by urban and rural remittances, land/people, rural residence and nonagricultural employment.

Using tabular data and semi-synthesis techniques to study the impact of past growth on poverty in the Chinese provinces, Chambers, Wu, and $\mathrm{Yao}(2008)$ found that previous short-term growth increases poverty; long-term growth previously increased poverty in provinces with slow growth, while poverty reduction in provinces grew faster. In addition, there is an inverse U-shaped relationship between poverty and income, i.e. at a lower income level, the poverty rate increases with income, while the opposite is kept at a higher income. However, higher savings rates or higher income inequalities make this trade-off less favorable.

Referring to the composition of growth in poverty alleviation, Loayza, and Raddatz(2010) focused on the structure of output growth itself, whereby the sector composition of growth and the intensity of labor. This could affect workers' wages and, therefore, reduce poverty. The authors considered the differential poverty-reducing impact of sectorial growth at different levels, and the role of unskilled labor intensity in that difference. The results reveal that, not only the size of economic growth, but also its composition, is also a problem of poverty reduction, with the greatest contribution from unskilled labor-intensive industries (agriculture, construction and manufacturing). The results are strong for the effects of exceptions, endogenous concerns, alternative explanations and various poverty measures.

Using data from the household survey to assess the impact of urbanization on income, expenditure, and poverty among rural households in Vietnam, Arouri, Youssef, and Nguyen(2017) found that urbanization stimulates the transition from farm to non-farm activities. Urbanization creates a tendency to reduce agricultural incomes of rural households in Vietnam, and increase non-agricultural income; it leads to an increase in the total income and consumption expenditure of rural households during urbanization. As such, urbanization in Vietnam contributes to reducing the expenditure poverty rate of rural households, albeit to a small extent.

Studying the role of food production growth on local poverty in Chile and Mexico, Cazzuffi, Soloaga, and Soloaga(2017) focused on food production as a multi-trait industry making it possible to help the poor, and incentives for spatial distribution can strengthen or reduce the potential for poverty reduction. Overall results show that growth in food production contributes to local poverty reduction.

In addition to studies on the direct effects of urbanization and economic growth on poverty reduction, there are a number of studies on their indirect effects on poverty reduction through manifestations such as health, employment, habitat, etc. Research by Afroz, Muhibbullah, and Morshed(2020) on the impact of information and communication technology on economic growth and population health in Malaysia indicates that the development of information and communication technology positively and significantly affects in the short and long term human health and longevity. Meanwhile, economic growth has no significant impact on the health of the population both in the short and long term.

Assessing social and economic development in areas of Kazakhstan and analyzing the disparities between the levels of economic and social development of regions, Nurlanova, Satybaldin, Brimbetova, and Kireyeva (2019) document that growth does not just include sustainable and balanced growth in all sectors of the economy, but also including equitable asset distribution and poverty reduction. To ensure comprehensive development from a spatial perspective, it is necessary to measure the current imbalance in the development of the economy and the social sector. They recognize the need for 
appropriate state programs to develop the most backward areas in the east and southeast of the country bordering China, which emphasizes the provision of state benefits and incentives to small- and medium-sized enterprises, developing transport and production infrastructure, and social facilities.

In summary, the results of the literature review indicate that most studies have focused solely on growth factors (growth structure, infrastructure, social services, trade liberalization, etc.) and factors of urbanization (free migration, land use, occupation change, etc.) as well as factors of poverty (place of residence, income, living standards, etc.). Very few studies reflect the impact of economic growth and urbanization on poverty reduction. This has led to the lack of extensive and comprehensive research on economies in general and specific comparisons between regions, countries, and different periods of the world. In fact, the studies carried out all show that an interaction between growth, urbanization and poverty reduction already exists, but the research methods used and conclusions of the various studies are contradicting each other. It is worth noting that the relationship between growth, urbanization, and poverty reduction in Vietnam in each period has different characteristics compared to other countries and regions in the world. Therefore, this study will focus on addressing the relationship between growth, urbanization, and poverty reduction in Vietnam through impact factors such as importexport value, GDP, urbanization rate, and the percentage of working-age laborers, with research data based on survey data published periodically by the General Statistics Office and the General Department of Vietnam Customs.

\section{Research Data, Model and Methods}

\subsection{Research Data}

In this study, the data is collected from secondary sources because of the study investigates the relationships between poverty rate of Vietnam's provinces with imports value, exports value, GDP value, labor, and urbanization rate. Therefore, secondary data is collected for these variables accordingly. Imports and exports value of Vietnam's provinces are collected from the website of the General Department of Vietnam Customs (2015). GDP value, labor, and urbanization rate are collected from the website of the General Statistics Office of Vietnam (2016). The research data collected during the period from when Vietnam officially joined the WTO (in 2006) to 2014 is the period when Vietnam moved from the group of low-income countries to the group of low middle-income countries. Also during this period, the poverty rate in Vietnam continued to decline, from 14.2\% (2006), 12.6\% (2008), 11.1\% (2010), $9.8 \%(2012)$ to $8.4 \%$ (2014). The GDP growth rate of Vietnam is also quite impressive(Duy \& Thai, 2016). If in 2006, the GDP was less than VND1 billion, by 2015, the economy will have reached nearly VND4.2 billion. However, by the end of 2018, Vietnam still has about eight million people living on less than US\$ 3.20 per day (The World Bank, 2019).

\subsection{Research Model}

Two models are used in this study - the fixed-effect model and the random-effect model. Both models are integrated as the original model as below:

$$
\begin{aligned}
\mathrm{P}_{\mathrm{t}}= & \alpha_{0}+\beta_{1} \log I M \mathrm{P}_{\mathrm{t}}+\beta_{2} \log \mathrm{EXP}_{\mathrm{t}}+\beta_{3} \log \mathrm{GDP}_{\mathrm{t}}+\beta_{4} \log \mathrm{L}_{\mathrm{t}} \\
& +\beta_{5} \log \mathrm{U}_{\mathrm{t}}+\varepsilon
\end{aligned}
$$

Where:

$\mathrm{P}_{\mathrm{t}}$ : Poverty rate of Vietnam in year $t$.

$\alpha_{0}$ : Constant.

$\beta_{1}, \beta_{2}, \beta_{3}, \beta_{4}, \beta_{5}:$ Regression coefficients of the independent variable.

$\operatorname{logIMP}$ : Natural logarithm of imports value of Vietnam in year $t$.

$\log \mathrm{EXP}_{\mathrm{t}}$ : Natural logarithm of exports value of Vietnam in year $t$.

$\operatorname{logGDP}:$ Natural logarithm of GDP of Vietnam in year . $\log \mathrm{L}_{t}$ : Natural logarithm of labor of Vietnam in year $t$.

$\mathrm{U}_{\mathrm{t}}$ : Urbanization rate of Vietnam in year $t$. The urbanization rate is calculated from the population in the urban area divided by the total population in year $t$.

$\varepsilon$ : Error of the equation.

Before running the above econometric model, running the unit root test is required. According to Gujarati (2003), a time series is stationary when it has mean value, variance, and covariance to be constant no matter what point in time. On the other hand, a time series is not stationary when its mean value and/or its variance/covariance are not constant. There are some statistical tests that are used to check a time series is stationary or not and the most used application is the unit root test. This test is so-called Augmented DickeyFuller (ADF) Test, which is provided by Dickey and Fuller (1981).

ADF Test is applied for the model below:

$$
\Delta \mathrm{y}_{\mathrm{t}}=\alpha+\beta_{\mathrm{t}}+\gamma \mathrm{y}_{(\mathrm{t}-1)}+\delta_{1} \Delta \mathrm{y}_{(\mathrm{t}-1)}+\ldots+\delta_{(\mathrm{p}-1)} \Delta \mathrm{y}_{(\mathrm{t}-\mathrm{p}+1)}+\varepsilon_{\mathrm{t} .}
$$

In which: is constant, is the coefficient on a time trend, is the lag order of auto-regression of $y_{t}$.

Generally, the result of the ADF test is dependent on and therefore, it is suggested that Akaike's Information Criterion (AIC) will be utilized accordingly. On the other hand, the value of $p$ is chosen when the AIC value is minimum. Moreover, the time series above is not stationary when the null hypothesis is rejected. 


\subsection{Research Methods}

The next step is to carry out two regressions models: one is a logistic regression with fixed effect and the other is a logistic regression with random effect. The fixed-effect model will be used when the researchers want to measure the impacts of variables that are varied over time. This model is very helpful in the case the researchers want to identify the causal relationships between independent variables and dependent variables within an entity. Each entity may have different characteristics and the differences may or may not lead to different impacts. For example, males and females have different assessments of certain issues. The fixed-effect model consists of a rationale of which something with the individual may bias the change of dependent variables. On the other hand, it means that there is a correlation between the entity's error term and dependent variables. In addition, another rationale in the fixed-effect model is that individual and time-variant characteristics are unique and these characteristics should not be correlated with individual characteristics. Moreover, the fixed-effect model will not take into account time-variant characteristics and therefore the researchers can measure the net effect of independent variables to dependent variables over time. The randomeffect model is also conducted in this study. Compared to the fixed-effect model, the random effect model comes up with different rationales. The rationale for fixed-effect model is that the variation across entities is random and it is not associated with the change of independent variables. Moreover, this rationale enables time-invariant variables to be independent variables in the regression model. On the other hand, the researcher will test which model is better through Hausman's Test. It is asserted that Hausman's Test is based on Chi-Square test and when p-value is less than 0.05 , the fixed-effect model is chosen and vice versa.

\section{Research Results}

\subsection{Descriptive Statistics}

\subsubsection{Variables Description}

The variable description is done by using descriptive statistics at provincial aggregated level with the result is obtained as in Table 1.

Table 1 shows:

The mean value of the provincial exports value is US $\$ 1.336185$ billion with standard deviation of US $\$ 3.590741$ billion. The min value of provincial exports value is equal to zero while the max value is equal to US\$31.35211 billion.

The mean value of the provincial imports value is US $\$ 1.354207$ billion with standard deviation of US $\$ 4.104182$ billion. The min value of provincial imports value is equal to zero while the max value is equal to US $\$ 30.84688$ billion.

The mean value of the provincial GDP value is US\$0.890754 billion with standard deviation of US $\$ 1.607919$ billion. The min value of provincial GDP value is equal to US\$0.0530702 while the max value is equal to US $\$ 17.73266$ billion.

The mean value of the provincial labor value is 791.3738 thousand people with standard deviation of 616.7779 thousand people. The min value of provincial labor value is equal to 172.8 thousand people while the max value is equal to 4188.5 thousand people.

The mean value of the provincial population value is $1,370.834$ thousand people with standard deviation of $1,135.318$ thousand people. The min value of provincial labor value is equal to 290 thousand people while the max value is equal to $7,981.9$ thousand people.

The mean value of the provincial urbanization value is 419.5543 thousand people with standard deviation of

Table 1: Variables Description

\begin{tabular}{|l|c|c|c|c|c|c|}
\hline \multicolumn{1}{|c|}{ Variable } & Unit & $\begin{array}{c}\text { Number of } \\
\text { observations }\end{array}$ & Mean & $\begin{array}{c}\text { Standard } \\
\text { deviation }\end{array}$ & Min value & Max value \\
\hline Exports value & US\$ billion & 567 & 1.336185 & 3.590741 & 0.00000 & 31.35211 \\
\hline Import value & US\$ billion & 567 & 1.354207 & 4.104182 & 0.00000 & 30.84688 \\
\hline GDP value & US\$ billion & 567 & 0.890754 & 1.607919 & 0.0530702 & 17.73266 \\
\hline Labor & Thousand people & 567 & 791.3738 & 616.7778 & 172.8 & $4,188.5$ \\
\hline Population & Thousand people & 567 & $1,370.834$ & $1,135.318$ & 290 & $7,981.9$ \\
\hline Urbanization & Thousand people & 567 & 419.5543 & 807.0567 & 45.1 & $6,554.7$ \\
\hline Poverty rate & $\%$ & 567 & 16.04374 & 10.755565 & 0.00000 & 58.2 \\
\hline Urban rate & $\%$ & 567 & 25.61093 & 16.322288 & 7.592033 & 87.28213 \\
\hline Labor rate & $\%$ & 567 & 58.33336 & 3.825709 & 47.60423 & 71.46111 \\
\hline
\end{tabular}


807.0567 thousand people. The min value of provincial labor value is equal to 45.1 thousand people while the max value is equal to $6,554.7$ thousand people.

The mean value of the provincial labor rate is $16.04374 \%$ with standard deviation of $10.75565 \%$. The min value of provincial labor rate is equal to $0 \%$ while the max value is equal to $58.2 \%$.

The mean value of the provincial urbanization rate is $25.61093 \%$ with standard deviation of $16.32288 \%$. The min value of provincial labor rate is equal to $7.592033 \%$ while the max value is equal to $87.28213 \%$.

\subsubsection{Description of the Poverty Rate}

This section explores the description of the poverty rate. The poverty rate of Vietnam averaged by provinces is shown in Figure 1.

Figure 1 shows that the average poverty rate in Vietnam decreased from $18.7 \%$ in 2006 to $11.1 \%$ in 2014. Detail data shows that only Ho Chi Minh City and Binh Duong are provinces that have successfully eradicated poverty. Both provinces have a poverty rate of zero percent in 2014 while the poverty rate of Ho Chi Minh City and Binh Duong in 2006 are both equal to $0.5 \%$ respectively. Hanoi, however, is dealing with a higher poverty rate during the period of 20062014. While Hanoi has a poverty rate in 2006 of $3.0 \%$, the poverty rate in this province has increased to $4.3 \%$ in 2014 . In addition, the top 10 provinces with a very high poverty rate are in northern mountain areas, including Lai Chau (35.3\%), Dien Bien (33.0\%), Ha Giang (28.2\%), Cao Bang (27.0\%), Son La (25.5\%), Lao Cai (25.3\%), Yen Bai (21.4\%), Kon Tum (19.0\%), Bac Kan (19.0\%), and Tuyen Quang (18.6\%).

\subsubsection{Description of Imports Value}

This section explores the description of imports value. Imports value of Vietnam is denominated through total value and average value by the province, which is shown in Figure 2.

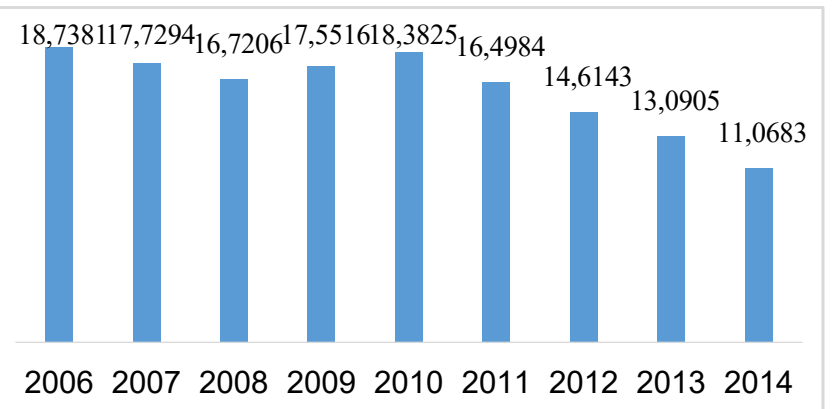

Figure 1: Average poverty rate by the province of Vietnam (\%)

Sources: General Statistics Office Of Vietnam (2016)

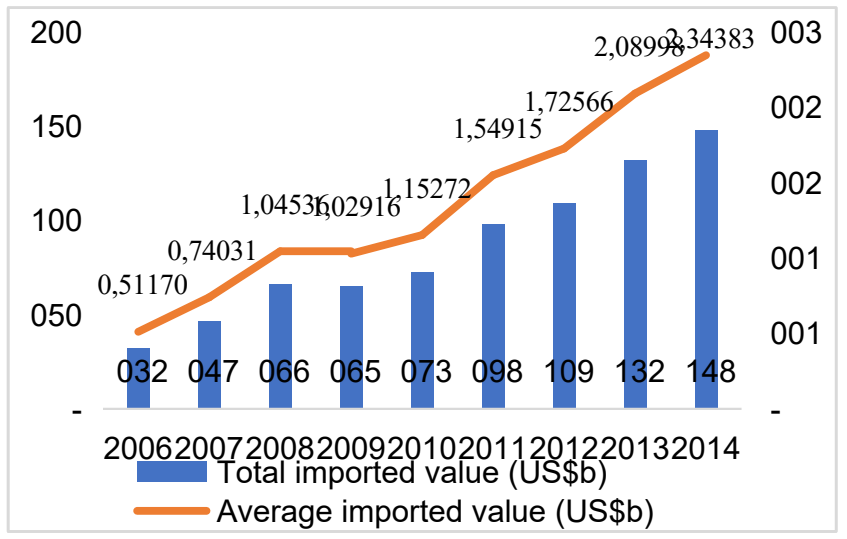

Figure 2: Total and average imports value of Vietnam (US\$ billion)

Sources: General Statistics Office Of Vietnam (2016)

Figure 2 shows that the total imports value of Vietnam surges from US\$32.24 billion in 2006 to US\$147.66 billion in 2014. Generally, the total imports value of Vietnam has continuously increased over time, except 2009 where total imports value is dropped from US $\$ 65.86$ billion to US $\$ 64.84$ billion. The average imports value by province is also increased over time, from US $\$ 0.51$ billion in 2006 to US\$2.34 billion in 2014. It is noted that the average imports value by province has decreased in 2009 when it dropped from US $\$ 1.05$ billion in 2008 to US $\$ 1.03$ billion in 2009 before increasing to US\$1.15 billion in 2010 . The highest imports value belonged to Hue with value of US $\$ 30.8$ billion in 2014, followed by Hanoi and Bac Ninh with total imports values of US\$24.4 billion and US\$17.7 billion, respectively.

\subsubsection{Description of the s Value}

This section explores the description of the exports value. Exports value of Vietnam comprises total exports value and average exports value by the province, which is shown in Figure 3.

Figure 3 shows that the total exports value of Vietnam increased from US\$33.71 billion in 2006 to US\$149.63 billion in 2014. The total exports value of Vietnam decreased during 2010 when it dropped from US\$65.13 billion in 2009 to US\$63.83 billion in 2010. Furthermore, the average exports value by province increased from US $\$ 0.54$ billion in 2006 to US $\$ 2.38$ billion in 2014 . It is noted that the average exports value by province dropped in 2010, from US\$1.03 billion in 2009 to US\$1.01 billion in 2010 before jumping to US $\$ 1.35$ billion in 2011. The highest exports value in 2014 belonged to Ho Chi Minh City at US\$31.4 billion, followed by Bac Ninh and Binh 


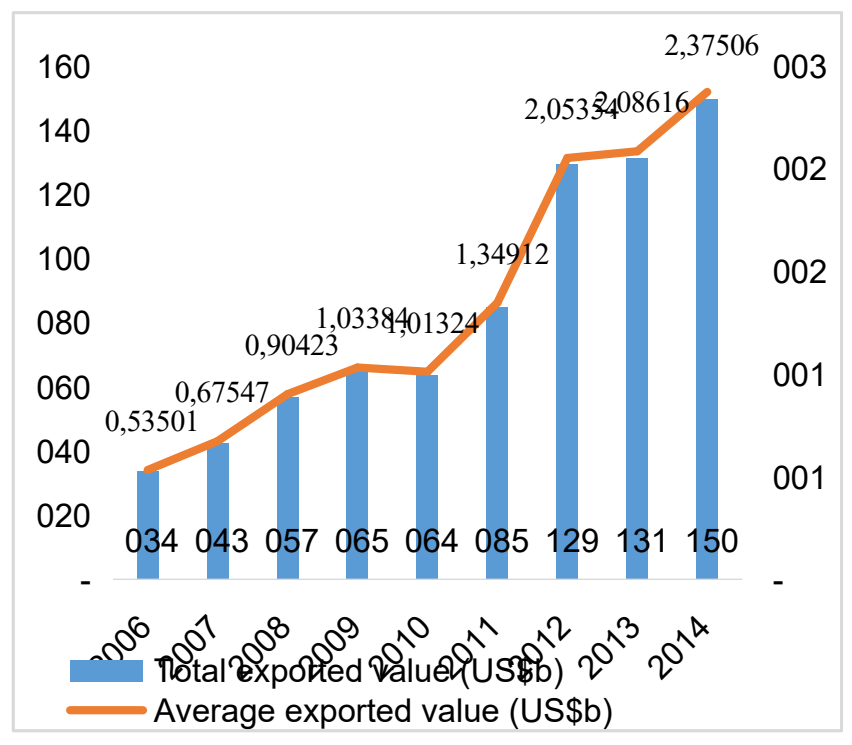

Figure 3: Total and average exports value of Vietnam (US\$ billion)

Sources: General Statistics Office of Vietnam (2016)

Duong with total exports values of US\$21.1 billion and US\$17.3 billion, respectively. Hanoi, which is the capital of Vietnam, has exports value of US\$11.1 billion and is ranked in fourth place, after one province in the South of Vietnam, Dong Nai, with total exports value in 2014 of US\$13.2 billion

\subsubsection{Description of the GDP Value}

This section explores the description of GDP value. The GDP value of Vietnam is denominated through total value and average GDP value by the province, which is shown in Figure 4.

Figure 4 shows that the total GDP value of Vietnam has two different trends. From 2006 to 2008, the GDP of Vietnam increased continuously, from US\$65.67 billion in 2006 to US\$100.85 billion in 2014. After 2008, the GDP of dropped to US\$41.06 billion in 2009 and it slightly increased to US\$45.46 billion in 2014. The average GDP by province repeats the same trend with total GDP value. It increased from US\$1.04 billion in 2006 to US\$1.60 billion in 2008 before decreasing to US\$0.65 billion in 2009. From 2009 to 2014, the average GDP by province in Vietnam has only slight increased, from US\$0.65 billion in 2009 to US\$0.72 billion in 2014 . Ho Chi Minh City, Hanoi, and Ba Ria - Vung Tau are provinces that have the highest GDP values in 2014, with the values of US\$8.3 billion, US\$4.1 billion, and US\$2.2 billion, respectively.

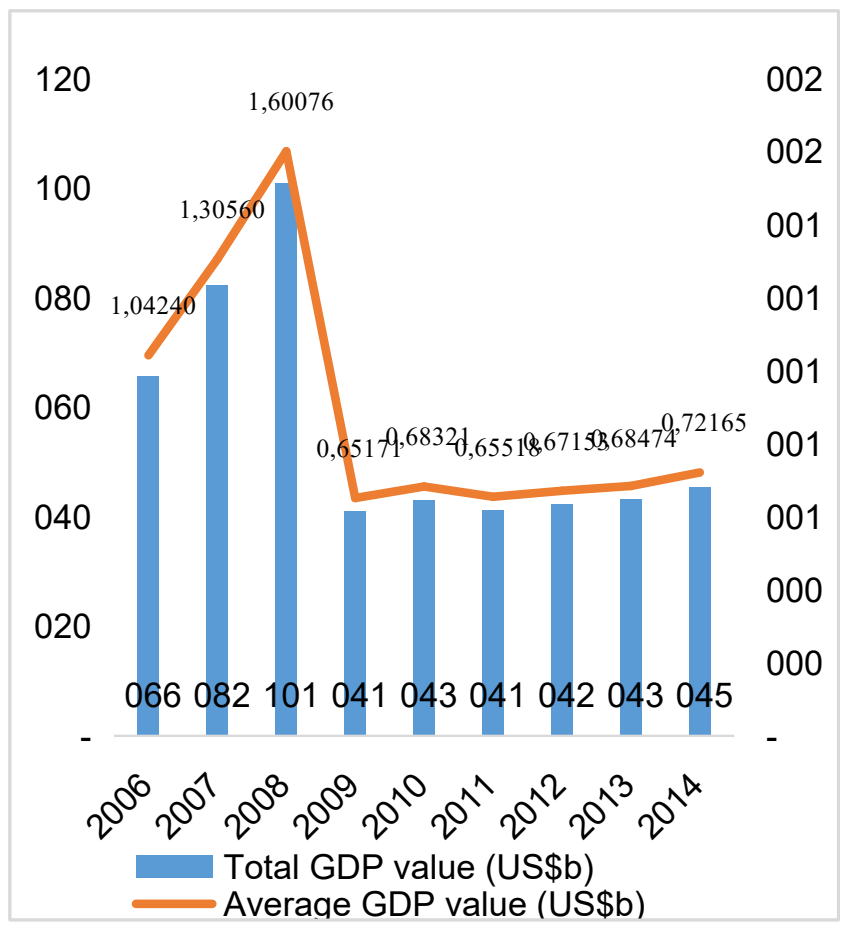

Figure 4: Total and average GDP value of Vietnam (US\$ billion)

Sources: General Statistics Office of Vietnam (2016)

\subsubsection{Description of the Labor Rate and the Urbanization Rate}

The average employment rate in Vietnam increased from $23.70 \%$ in 2006 to $27.75 \%$ in 2014. Da Nang, Ho Chi Minh City, and Binh Duong are the provinces that have the highest employment rates with values of $87.3 \%, 82.1 \%$, and $76.8 \%$ in 2014. It is noted that the employment rate is derived from the number of the population 15-years old and older divided by the total population of the province(General Statistics Office Of Vietnam, 2016).

The average urbanization rate in Vietnam increased from $55.57 \%$ in 2006 to $60.35 \%$ in 2014 . Big cities like Hanoi, Ho Chi Minh City, and Da Nang have urban rates of $53.00 \%$, $53.09 \%$, and $51.14 \%$ in 2014 , respectively. It is noted that the urban rate is derived from the number of the population that is living in urban area divided by the total population of the province(General Statistics Office Of Vietnam, 2016).

\subsection{Estimated Results}

\subsubsection{The Result with the Fixed Effect}

The estimated result with the fixed effect is presented in Table 2. 
Table 2: Estimated result with fixed effect

\begin{tabular}{|c|c|c|c|c|c|c|}
\hline \multirow{3}{*}{ R-Square } & Within & \multicolumn{5}{|c|}{0.3412} \\
\hline & Between & \multicolumn{5}{|c|}{0.3566} \\
\hline & Overall & \multicolumn{5}{|c|}{0.3525} \\
\hline \multicolumn{2}{|l|}{$F(5,499)$} & \multicolumn{5}{|c|}{51.69} \\
\hline \multicolumn{2}{|l|}{ Prob $>\mathrm{F}$} & \multicolumn{5}{|c|}{0.0000} \\
\hline povp & coefficient & standard err & $\mathrm{T}$ & $P$ & \multicolumn{2}{|c|}{ 95\% Confidence Interval } \\
\hline $\exp$ & -0.1614842 & 0.0399526 & -4.04 & 0.000 & -0.2399803 & -0.0829882 \\
\hline imp & -0.1383836 & 0.0239677 & -5.77 & 0.000 & -0.1854736 & -0.0912935 \\
\hline gdp & -0.055378 & 0.0944812 & -0.059 & 0.558 & -0.2410081 & 0.130252 \\
\hline urbp & -0.0062506 & 0.0016827 & 3.71 & 0.000 & 0.0029447 & 0.0095566 \\
\hline labp & -3.915207 & 0.4777659 & -8.19 & 0.000 & -4.853888 & -2.976527 \\
\hline constant & 16.4208 & 1.801091 & 9.12 & 0.000 & 12.88214 & 66.18674 \\
\hline
\end{tabular}

With fixed effects to be applied, the obtained result shows that independent variables (exports value, imports value, GDP value, urbanization rate, and employment rate) can explain $34.21 \%$ of the change in the poverty rate. F-Test has a value of 5.69 and the $p$-value is less than 0.05 . Thus, the relationship of independent variables to dependent variable is statistically significant at $5 \%$ of the confidence interval.

In terms of the relationship between exports value and poverty rate, the coefficient is equal to -0.1614842 and p-value of T-Test is 0.000 and it is lower than 0.05 . Thus, the exports value does have a statistically significant relationship with the poverty rate.

In terms of the relationship between imports value and poverty rate, the coefficient is equal to -0.1383836 and p-value of T-Test is 0.000 and it is less than 0.05 . Thus, the imports value does have a statistically significant relationship with the poverty rate.

In terms of the relationship between GDP value and poverty rate, the coefficient is equal to -0.055378 , but p-value of T-Test is 0.558 and it is higher than 0.05 . Thus, the GDP value does not have a statistically significant relationship with the poverty rate.

In terms of the relationship between urbanization rate and poverty rate, the coefficient is equal to -0.0062506 , but p-value of T-Test is 0.000 and it is lower than 0.05 . Thus, urbanization rate does have a statistically significant relationship with the poverty rate.

In terms of the relationship between employment and poverty rate, the coefficient is equal to -3.915207 and p-value of T-Test is 0.000 and it is lower than 0.05 . Thus, employment does have a statistically significant relationship with the poverty rate. On the other hand, it means that the poverty rate by province in Vietnam will decreased when the employment rate increases.

\subsubsection{The Result with the Random Effect}

The estimated result with the random effect and Generalized Least Square (GLS) is presented in Table 3.

With random effects to be applied, the obtained result shows that independent variables (exports value, imports value, GDP value, urbanization rate, and employment rate) can explain $31.2 \%$ of the change in the poverty rate. ChiSquare Test has value of 328.43 and p-value is less than 0.05 . Thus, the explanation of the independent variables to dependent variable is statistically significant at $5 \%$ of confidence interval.

In terms of the relationship between exports value and poverty rate, the coefficient is equal to -0.2575763 and $\mathrm{p}$-value of T-Test is 0.000 and it is lower than 0.05 . Thus, the exports value does have a statistically significant relationship with the poverty rate.

In terms of the relationship between imports value and poverty rate, the coefficient is equal to -0.1584175 and $\mathrm{p}$-value of T-Test is 0.000 and it is lower than 0.05 . Thus, the imports value does have a statistically significant relationship with the poverty rate.

In terms of the relationship between GDP value and poverty rate, the coefficient is equal to --0.1217214 and $\mathrm{p}$-value of T-Test is 0.137 and it is higher than 0.05 . Thus, the GDP value does not have a statistically significant relationship with the poverty rate.

In term of the relationship between urbanization rate and poverty rate, the coefficient is equal to 0.001798 , but p-value of T-Test is 0.053 and it is higher than 0.05 and lower than 0.10 . Thus, the urbanization rate does not have a statistically significant relationship with the poverty rate at $5 \%$ of confidence interval, but urbanization rate does have a statistically significant relationship with poverty rate at 
Huyen Thi Thanh NGUYEN, Chau Van NGUYEN, Cong Van NGUYEN /

Table 3: Estimated result with random effect GLS regression

\begin{tabular}{|c|c|c|c|c|c|c|}
\hline \multirow{3}{*}{ R-Square } & Within & \multicolumn{5}{|c|}{0.3152} \\
\hline & Between & \multicolumn{5}{|c|}{0.5327} \\
\hline & Overall & \multicolumn{5}{|c|}{0.5154} \\
\hline \multicolumn{2}{|c|}{ Wald Chi2 (5) } & \multicolumn{5}{|c|}{328.43} \\
\hline \multicolumn{2}{|l|}{ Prob $>\mathrm{F}$} & \multicolumn{5}{|c|}{0.0000} \\
\hline povp & coefficient & standard err & $\mathrm{T}$ & $P$ & \multicolumn{2}{|c|}{ 95\% Confidence Interval } \\
\hline $\exp$ & -0.2575763 & 0.0402922 & -6.39 & 0.000 & -0.3365476 & -0.178605 \\
\hline imp & -0.1584175 & 0.0246849 & -6.42 & 0.000 & -0.206799 & -0.110036 \\
\hline gdp & -0.1217214 & 0.081954 & -1.49 & 0.137 & -0.2823482 & 0.0389054 \\
\hline urbp & 0.001798 & 0.0009277 & 1.94 & 0.053 & -0.0000204 & 0.0036163 \\
\hline labp & 0.001798 & 0.3063744 & -6.90 & 0.000 & -2.715328 & -1.514363 \\
\hline constant & 9.815821 & 1.14531 & 8.57 & 0.000 & 7.571054 & 12.06059 \\
\hline
\end{tabular}

$10 \%$ of confidence interval. On the other hand, it means that poverty rate by province in Vietnam will decreased when urbanization rate increases at $10 \%$ of confidence interval.

In terms of the relationship between employment and poverty rate, the coefficient is equal to 0.001798 , but p-value of T-Test is 0.000 and it is less than 0.05 . Thus, the employment rate does have a statistically significant relationship with the poverty rate.

\subsubsection{The Hausman's Test}

After running both fixed and random effects, the next step is to choose which model is better. This can be done by using Hausman's Test. The result of Hausman's Test is presented in Table 4.

Table 4 shows the difference between the fixed-effect model (FEM) and the random-effect model (REM). The difference between these two models is tested by the Chi-square test and if $\mathrm{p}$-value is less than 0.05 , the fixed-effect model should be used instead of the random-effect model. Table 4 returns p-value of 0.000 and it is lower than 0.05 , so that the fixed-effect model will be better than the random-effect model.

\section{Conclusions}

From the research results, some conclusions can be drawn from the relationships between the poverty rate and its independent variables, including exports value, imports value, GDP value, employment rate, and urbanization rate.

The fixed-effect model shows that independent variables can explain $33.26 \%$ of the change of dependent variable. However, only the employment rate has a coefficient statistically significant at $5 \%$ confidence interval. Other independent variables have a coefficient with p-values higher than 0.05 . In addition, the coefficient of the employment rate is negative, so that when employment rate increased, the poverty rate in provinces will decreased and vice versa. The GDP value and urbanization rate have negative impacts on poverty rate, but the impacts are not statistically significant at $5 \%$ of confidence interval.

Research results from the fixed-effect model also show that, while GDP growth rate has negative and significant impact on poverty rate, urbanization rate has positive and significant impact on the poverty rate. On the other hand, it means that the GDP growth rate promotes the reduction of

Table 4: Hausman's Test

\begin{tabular}{|l|c|c|c|c|}
\hline & (b) FEM & (B) REM & (b-B) Difference & SE \\
\hline exp & -0.1614842 & -0.2575763 & 0.096092 & 0 \\
\hline imp & -0.1383836 & -0.1584175 & 0.0200339 & 0 \\
\hline gdp & -0.055378 & -0.1217214 & 0.0663434 & 0.0470133 \\
\hline urbp & 0.0062506 & 0.001798 & 0.0044527 & 0.3665992 \\
\hline labp & -3.915207 & -2.114845 & -1.800362 & 0.00144038 \\
\hline Chi2(5)0 = 322.28; Prob > Chi2 = 0.000 \\
\hline
\end{tabular}


poverty rate, but higher urbanization rate promotes higher poverty rate.

From the conclusion above, we make some policy recommendations to further reduce the poverty rate in Vietnam's provinces. Firstly, further decentralize the localities in the implementation of hunger eradication and poverty alleviation programs, ensuring harmony between their responsibilities and their powers; ministries and sectors should focus on developing mechanisms, policies, building criteria, creating resources, training staff, guiding and monitoring; on-the-spot mobilization and implementation is the responsibility of the commune, district and province. Promote local initiative, dynamic role of mass organizations and people in the implementation process.

Secondly, the 35 poorest mountainous districts should be included in the investment plan. China's experience in solving this problem is very successful. In Vietnam, Ho Chi Minh City, Dong Nai, Yen Bai and others also tend to have done so. For ethnic minority people in the Central Highlands, mobilize and assign tasks to state forestry enterprises; the economic units of the military; youth economics helps compatriots with appropriate forms. It is necessary to promote the role of local people in the project implementation process, creating a solid link between local authorities, mass organizations, and people to reduce the situation of poverty again in many localities.

Thirdly, improve the mechanism of mobilization through allocation and management of resources in the direction of multi-source, local importance in each locality. At the same time, to adopt appropriate policies to attract enterprises investing in mountainous areas, especially land and tax incentives. It is necessary to calls for support from other countries and international organizations, creating strong financial strength for poor areas.

Fourthly, the system of management mechanism has been reformed with clearly defining the functions and tasks of ministries, central agencies and localities. Strengthening capacity and authority in managing and administering program implementation for the province; clarify the rights and responsibilities of poor people, poor households, poor communes, overcome dependency. Establish mechanisms to encourage households and communes to become self-reliant to escape poverty and to mobilize and use capital effectively. In order to successfully eradicate hunger and alleviate poverty, it is necessary to encourage the enrichment and create conditions for all capable persons to invest, produce, and trade in a proper way.

Fifth, increase communication and advocacy to raise people's awareness and promote the role of officials in poverty reduction. The work of officials, especially those directly leading in poverty reduction, plays a decisive role. On the other hand, it is necessary to improve the capacity of officials at all levels, especially at the grassroots level, to reduce poverty and enhance workers' position.

\section{References}

Afroz, R., Muhibbullah, M., \& Morshed, M. N. (2020). Impact of Information and Communication Technology on Economic Growth and Population Health in Malaysia. Journal of Asian Finance, Economics and Business, 7(4), 155-162. https://doi. org/10.13106/jafeb.2020.vol7.no4.155.

Arouri, M., Youssef, A., \& Nguyen, C. (2017). Does urbanization reduce rural poverty? Evidence from Vietnam. Economic Modelling, 60, 253-270. https://doi.org/10.1016/j. econmod.2016.09.022.

Calì, M., \& Menon, C. (2013). Does Urbanization Affect Rural Poverty? Evidence from Indian Districts. The World Bank Economic Review, 27(2), 171-201. https://doi.org/10.1093/ wber/lhs019.

Cazzuffi, C., Soloaga, M. P.-L., \& Soloaga, I. (2017). Local poverty reduction in Chile and Mexico: The role of food manufacturing growth. Food Policy, 68, 160-185. https://doi.org/10.1016/j. foodpol.2017.02.003.

Chambers, D., Wu, Y., \& Yao, H. (2008). The impact of past growth on poverty in Chinese provinces. Journal of Asian Economics, 19(4), 348-357. https://doi.org/10.1016/j.asieco.2008.04.004.

Dickey, D. A., \& Fuller, W. A. (1981). Likelihood Ratio Statistics for Autoregressive Time Series with a Unit Root. Econometrica, 49(4), 1057-1072. DOI: 10.2307/1912517.

Duy, C., \& Thai, H. (2016, 3 29). Vietnam's economy for 10 years under Prime Minister Nguyen Tan Dung. (VnEconomy, Producer, \& Vietnam Economic Times Group) Retrieved 9 2018, from News: http://vneconomy.vn/thoi-su/kinhte-viet-nam-10-nam-duoi-thoi-thu-tuong-nguyen-tandung-20160329012359222.htm

General Department of Vietnam Customs. (2015, 12). General statistical indicators. Retrieved 10 2017, from Home> Customs Statistics > Statistics Data > Periodic statistics: https:// www.customs.gov.vn/Lists/ThongKeHaiQuan/SoLieuDinhKy. aspx?Group $=\mathrm{S} \%$ uled $1+\mathrm{li} \% \mathrm{u} 1 \mathrm{ec} 7 \mathrm{u}+$ th $\%$ uled $1 \mathrm{ng}+\mathrm{k} \% \mathrm{u} 00 \mathrm{ea}$

General Statistics Office of Vietnam. (2016, 12). Statistics. (Statistical Documentation and Service Centre) Retrieved 10 2018, from Home: http://www.gso.gov.vn/Default en.aspx?tabid=766

Giang, L. T., Nguyen, C. V., \& Nguyen, H. Q. (2020). The Impacts of Economic Growth and Governance on Migration: Evidence from Vietnam. The European Journal of Development Research, https://doi.org/10.1057/s41287-020-00262-3.

Gujarati, D. N. (2003). Basic Econometrics (4th Ed.). New York: McGraw-Hill.

Jack, M. (2009). Urbanisation, Sustainable Growth and Poverty Reduction in Asia. IDS Bulletin 37(3), 101-114. DOI: 10.1111/ j.1759-5436.2006.tb00273.x. 
Le, T. B. (2020, 2 22). Headache when Vietnam suddenly became a developed country. Retrieved 2 2020, from Analysis Awareness - Topic Analysis: https://cafeland.vn/phan-tich/daudau-khi-viet-nam-bong-tro-thanh-nuoc-phat-trien-85458.html

Loayza, N. V., \& Raddatz, C. (2010). The composition of growth matters for poverty alleviation. Journal of Development Economics, 93(1), 137-151. https://doi.org/10.1016/j. jdeveco.2009.03.008.

Mitra, D. (2016). Trade liberalization and poverty reduction: Trade can reduce poverty when accompanied by appropriate policies and institutions. IZA World of Labor, 1-10. DOI: 10.15185/izawol.272.

Nguyen, C. V., \& Pham, N. M. (2018). Economic growth, inequality, and poverty in Vietnam. Asian-Pacific Economic Literature, 32(1), 45-58. DOI:10.1111/apel.12219.

Nguyen, H. H., \& Nguyen, N. V. (2019). Factor Affecting Poverty and Policy Implication of Poverty Reduction: A Case Study for the Khmer Ethnic People in Tra Vinh Province, Viet Nam. Journal of Asian Finance, Economics and Business, 6(1), 315319. http://doi.org/10.13106/jafeb.2019.vol6.no1.315

Nguyen, H. T., Nguyen, H. T., Nguyen, H. T., \& Nguyen, C. V. (2020). The Impact of International Integration on the Inequality of Income between Rural and Urban Areas in Vietnam. Journal of Asian Finance, Economics and Business, 7(3), 277-287. https://doi.org/10.13106/jafeb.2020.vol7.no3.277.

Nurlanova, N. K., Satybaldin, A. A., Brimbetova, N. Z., \& Kireyeva, A. A. (2019). Reduction of Economic Disparities in the Regions of Kazakhstan Based on Inclusive Development. Journal of Asian Finance, Economics and Business, 6(2), 299307. https://doi.org/10.13106/jafeb.2019.vol6.no2.299.

Omolo, M. W. (2012). The impact of trade liberalization on poverty in Kenya: a microsimulation. The 15th Annual Conference on Global Economic Analysis (pp. 01-35). Geneva, Switzerland: Center for Global Trade Analysis Department of Agricultural Economics Purdue University.

Ravallion, M., Chen, S., \& Sangraula, P. (2007). New Evidence on the Urbanization of Global Poverty. Population and Development Review, 33(4), 667-701. https://doi.org/10.1111/ j.1728-4457.2007.00193.x.

Shah, A. (2011, 11 12). Poverty Around The World. Retrieved 10 2019, from Global Issues - Social, Political, Economic and Environmental Issues That Affect Us All: https://www. globalissues.org/article/4/poverty-around-the-world

Sinding, S. W. (2009). Population, poverty and economic development. Philosophical Transactions of the Royal Society B, 364, 3023-3030. DOI: 10.1098/rstb.2009.0145.

The World Bank. (2019, 10 18). Overview. Retrieved 122019 , from Where We Work Vietnam: https://www.worldbank.org/ en/country/vietnam/overview

Turok, I., \& McGranahan, G. (2020). Urbanisation and Economic Growth: The Arguments and Evidence for Africa and Asia. Environment \& Urbanization, 4(2), 109-125. DOI: $10.1177 / 2455747119890450$. 